\title{
Seismic Performance Assessment and Upgrading of Al- Karamah Teaching Hospital Building under 2017 Halabjah Earthquake
}

\author{
Haider A. Abass ${ }^{1}$, Husain K. Jarallah ${ }^{2}$ \\ \{hiaderaabass@uomustansiriyah.edu.iq ${ }^{1}$,khalfdce@uomustansiriyah.edu.iq ${ }^{2}$ \} \\ Department of Civil Engineering, College of Engineering, Mustansiriyah University, Baghdad - Iraq ${ }^{1,2}$
}

\begin{abstract}
Seismic evaluation and retrofitting are considered very important issues in the maintenance and strengthening in terms of buildings resistance against earthquake loads. The study aims to apply a practical way, such as the seismic assessment of the Al-Karamah Teaching Hospital -Thalassemia Centre Building in Baghdad, Iraq. It is involving the analysis and converts 2017 Halabjah earthquake records to the response spectrum. By using the pushover analysis, the results were compared with results of (Design Basis Earthquake (DBE), and Maximum Considered Earthquake (MCE)) elastic response spectrum of the Iraqi Seismic Code (ISC-2017). The results were carried out in terms of capacity curves, performance level according to ATC-40, and the plastic hinge mechanism. Regarding the practical method aforementioned, the results illustrated that the plastic hinges formed in the primary elements (structural elements). The retrofitting mechanism was conducted by joining two parts of the Thalassemia Centre Building to be one entity. This technique leads to an increase in the base shear to $(61.77 \%, 51.51 \%, 28.51 \%$, and $70.85 \%)$ for two parts in the two directions ( $\mathrm{X}$ and $\mathrm{Y})$ respectively, a decrease in the roof displacement to $(8 \%, 27 \%$, $108.16 \%$, and $387 \%$ ) for two parts in the two directions (X and $\mathrm{Y}$ ) respectively, neglecting the torsion effect, a decrease in the story drift and change the performance level of the building to the Immediate Occupancy (IO) level.
\end{abstract}

Keywords: Response Spectrum, Moment- Curvature Analysis, Iraqi Seismic Code, 2017 Halabjah Earthquake, Plastic Hinge.

\section{Introduction}

A complete study of the seismic evaluation will be much too wide for this study to undertake. However, several excellent references can be used as a starting point for the seismic evaluation such (ATC 40 [1]), (FEMA-365 (2)], and (FEMA-273 (3)]. The recent contributions of the seismic evaluation and previous efforts are most closely linked to the current project's requirements. For performance assessment, selecting suitable damage parameters is critical. Overall lateral deflection, inter-story drift, and plastic hinge rotation are the most commonly utilized damage parameters. Overall defection isn't usually a sign of damage, but inter-story drift is a good indicator of lateral load-resisting system deterioration [4]. They are also good damage guidelines since the maximum values of a member's or joint's rotations, curvature, and ductility factors are directly related to the element deformation capabilities. However, using merely the maximum value of each of these factors to calculate the total damage caused by a cyclic reversal of deformation may be insufficient [5]. For such cases, damage measures that account for both full deformation and cyclic effects have been developed. Both indices may be used to assess the 
overall state of a structure [6]. Many existing systems are vulnerable, which may explain structural vulnerabilities and low ductility. Common structural weaknesses include lakes in the load direction, strength and rigidity dislocations, (perpendicular, lateral, and weight) abnormalities, weak column and strong beam, and eccentricity. Insufficient shear reinforcement, poor confinement, and a lack of anchorage length of the beam-reinforcement bars are all examples of low ductility details [7]. Other displacement-based damage metrics include curvature and ductility factors, lateral drift or roof displacement, inter-story drift, member or joint rotations, and other displacement-based damage parameters. Inter-story drift and lateral drift are two often utilized criteria that are part of the direct development of performance level. IDR (inter-story drift) is a key engineering response quantity and structural performance indicator. It's calculated by dividing the difference in translational displacement for two consecutive floors by the story height. While the maximum values of displacement-based damage parameters provide a good measure of damage, they ignore the damage caused by cyclic deformation reversal during earthquakes [8]. This study is concerned to implement a practical way of seismic evaluation and rehabilitation on the Al-Karamah Teaching HospitalThalassemia Centre building. This building was impacted by the 2017 Halabjha earthquake, and the main elements were damaged. The study analyzed the building by using pushover analysis. The results were carried out within capacity curves (Base shear versus Roof displacement), performance level, and plastic hinge mechanism. The technique that used in this study was more effective to retrofit the building, it decreases the story drift to the acceptable limits, neglects the torsion effect, and changes the performance level of the building to Immediate Occupancy IO level.

\section{General Description}

\subsection{Description of the Thalassemia Centre Building}

Al-Karamah Teaching Hospital is a large hospital to a very big population in the side of AlKarkh (the western shore of the Tigris River as it ran through Baghdad) of Baghdad city in Iraq. It is considered one of the oldest and most famous major hospitals in Iraq. This hospital was established in 1927 with an area of 1.25 Hectare (72000 ft2) of capacity (445) beds. The hospital includes the consulting, emergency building, and departments (internal, surgical, private ward, urinary tract, eyes, ear, nose, throat, burns center, gynecology, obstetrics department, pediatrics department, fractures, and bones). The buildings already constructed are (1) Al- Hayat Dialysis Centre, (2) Thalassemia Centre, (3) Respiratory Care Centre, Nadori Surgery Centre, (4) Stem Cell Centre, (5) Centre for Diseases and dialysis (children), laboratories, unitsof supportive examinations. The hospital receives more than (18000) thousand patients per month and provides medical and health services to all citizens from all Iraqi provinces. In 2016, the Thalassemia Centre Building, which houses 195 patient beds, was completed. The center building is a six-story structure with a total area of around $1400 \mathrm{~m} 2$. From an architectural standpoint, the first story is for consultants, the second story is for laboratories, the third flooris for hospital administration, and the other floors are designated as patient admissions corridors. The expansion joint divides the building into two sections. An expansion joint connects each block. The outside dimensions of the structure are approximately $(50.4$ x 32.4) $\mathrm{m}$. The first component is rectangular in plan and has overall plan dimensions of 50.4 x $15.6 \mathrm{~m}$. The second part is L shape in the plane, the first length is $21.6 \mathrm{~m}$ and the second length is $14.4 \mathrm{~m}$, while the 
width is $32.4 \mathrm{~m}$. The first story height is $6.7 \mathrm{~m}$, the second and third story is $5.7 \mathrm{~m}$, and the typical 4th,5th, and 6th story height is $4 \mathrm{~m}$. Fig 1 illustrates the interfaces of the Thalassemia Centre Building. From the structural point of view, Thalassemia Centre Building is on a raft foundation resting on medium-stiff soil. The foundation was meant to be 1.37 meters beneath the original ground level. The foundation slab is 0.9 meters thick. Under the raft foundation, a $50 \mathrm{~mm}$ thick lean concrete has been laid. Using a slab steel frame, the first, second, and third stories are divided to $1.8 \mathrm{~m}$ from the bottom slab level, and the secondary stories are used to fix the mechanical components (ducts, e.g.). A system of slabs and beams supported by columns carries the weight of the entire structure as well as the weight superimposed on the building. The slab system is a two-way waffle slab with a $70 \mathrm{~mm}$ concrete slab on all floors. Between the two sections, there is a $175 \mathrm{~mm}$ clean gap. The plan with the column orientation is shown in Fig.2.

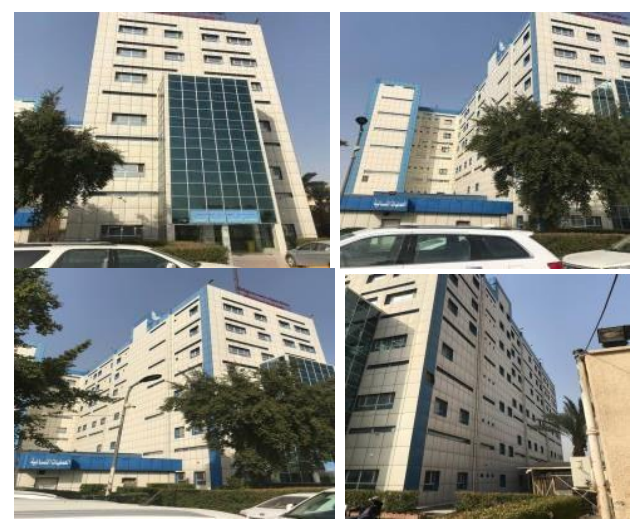

Fig. 1. Thalassemia Center Building Interfaces.

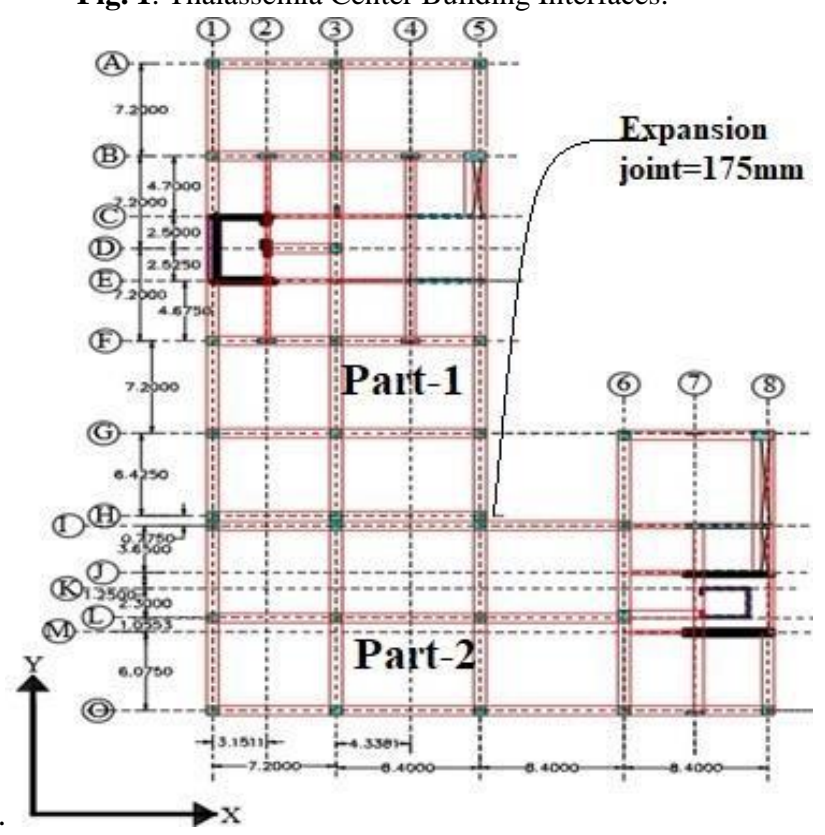

Fig. 2. Floor Framing Plan (All Dimensions in Meter Unit). 


\subsection{Description of 2017 Halabjah Earthquake}

On November 12th, 2017, at 18:18:15 GMT, one of the greatest earthquakes was recorded struck the Iraq-Iran region. According to the US Geological Survey, the earthquake had a magnitude of 7.3 degrees on the Richter scale. The earthquake was named Halabjah earthquake, a city in Iraq's Kurdistan region because the epicenter was only 32 kilometers south of Halabjah city. Although the epicenter was near Kermanshah province in Iran, at $34.840^{\circ} \mathrm{N}$ latitude $45.924^{\circ} \mathrm{E}$ longitude, Fig 3 depicts the location of the Halabjah earthquake.

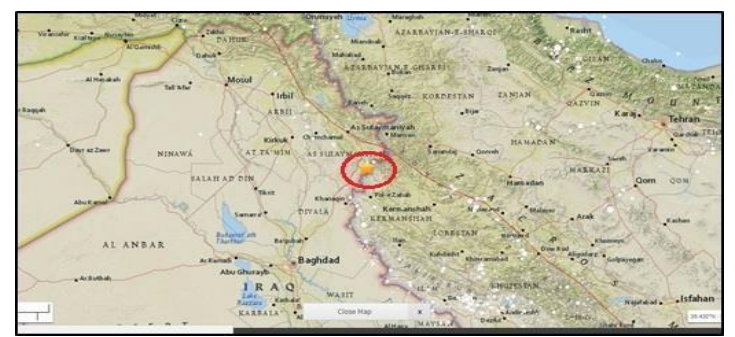

Fig. 3. Regional Map Showing November 12, 2017, Earthquake.

\subsection{Field Investigations}

The Thalassemia Centre Building was damaged in the 2017 Halabjah earthquake, according to an inquiry. Figure 4 depicts the building's structural and non-structural damages.

(a)
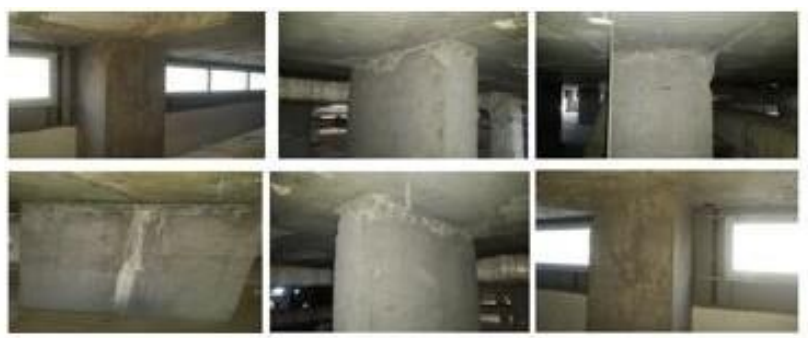

(b)
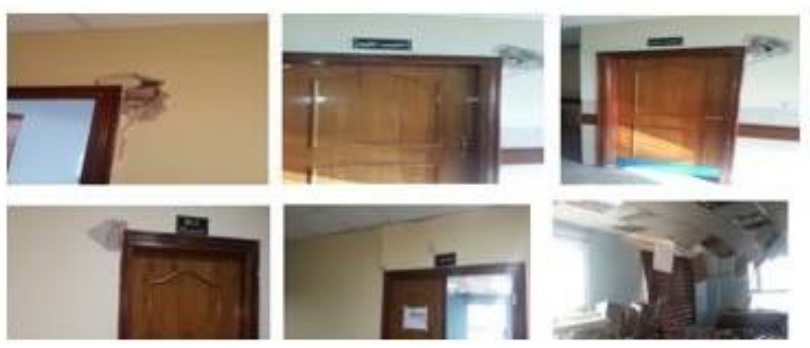

Fig. 4. Damages in Thalassemia Centre Building. a) Structural Elements Damages and b) NonStructural Elements Damages. 


\section{Materials Properties}

The material parameters acquired from the structural drawings are shown in Table 1. The specified (default values) are translated to 'anticipated' values by a factor greater than one, according to ACI 369 R-11 [9].

Table 1. Materials Properties

\begin{tabular}{lcccc}
\hline \multicolumn{4}{c}{ Concrete } & \multicolumn{2}{c}{ Reinforcing Steel } & \\
& $\begin{array}{l}\text { Specified } \\
\text { cylinder } \\
\text { strength } \\
(\mathrm{MPa})\end{array}$ & $\begin{array}{l}\text { Expected } \\
\text { cylinder } \\
\text { strength } \\
(\mathrm{MPa})\end{array}$ & $\begin{array}{c}\text { Specified } \\
\text { yield } \\
\text { strength } \\
\text { (Mpa) }\end{array}$ & $\begin{array}{c}\text { Expected } \\
\text { yield } \\
\text { strength } \\
(\mathrm{Mpa})\end{array}$ \\
& & & & \\
Beam & 30 & 45 & 420 & 525 \\
Column & 30 & 45 & 420 & 525 \\
\hline
\end{tabular}

\section{Building Modelling}

\subsection{Nonlinear Modeling of Beam-Column Frames}

As frame elements, the centerlines of beams and columns are connected at nodes. There are five beam-column frames in the transverse direction and seven beam-column frames in the longitudinal direction. The first, second, and third stories' steel frames were computed and distributed as a concentrated force on the columns. The weight of the two-way waffle slabs with ribs was distributed to the surrounding main beams in triangular and trapezoidal segments.

\subsubsection{Moment Curvature Analysis}

A nonlinear geometrical model is used to model the beam-column frames. Using SAP 2000 Section Designer [10].

\subsubsection{Results of Moment Curvature Analysis}

Section Designer in SAP 2000 generated a moment-curvature analysis of beams sections [10]. Positive and negative moment-curvature of the beams have been established in three locations, two at the end span and one in the middle. The moment-curvature connection was idealized linearly [11,12]. The moment-curvature of beam-1 is shown in Fig 5, and the remaining beams have been defined using the same way. 


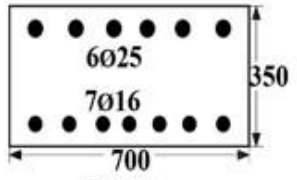

Mid-Span

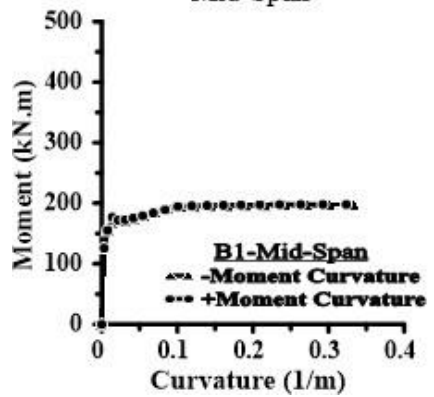

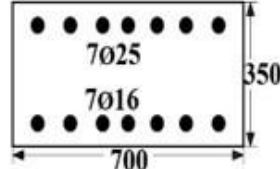

$\operatorname{Sec}(\mathrm{Q}-\mathrm{Q})$

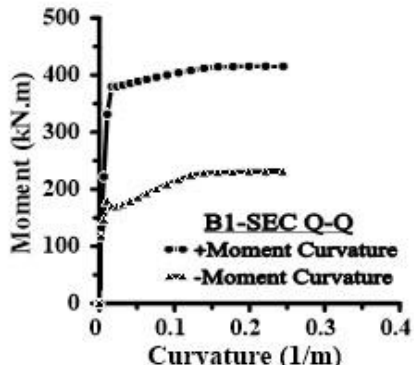

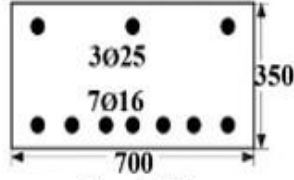

$\operatorname{Sec}(\mathrm{R}-\mathrm{R})$

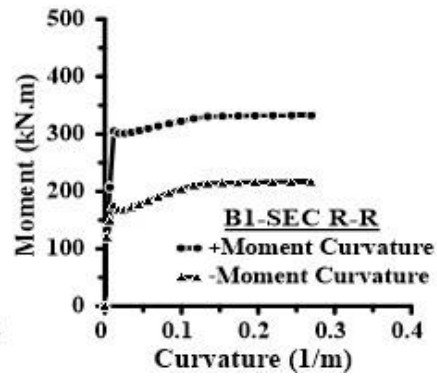

Fig.5. Moment-Curvature Relationship of Beams.

\subsubsection{Results of Columns-Interaction}

The moment-curvature and columns interaction relationship of the building columns is defined using SAP2000 Section Designer [10]. The results of existing column-1 interaction curves with various angles are shown in Fig 6, and the other columns were defined using the same way.
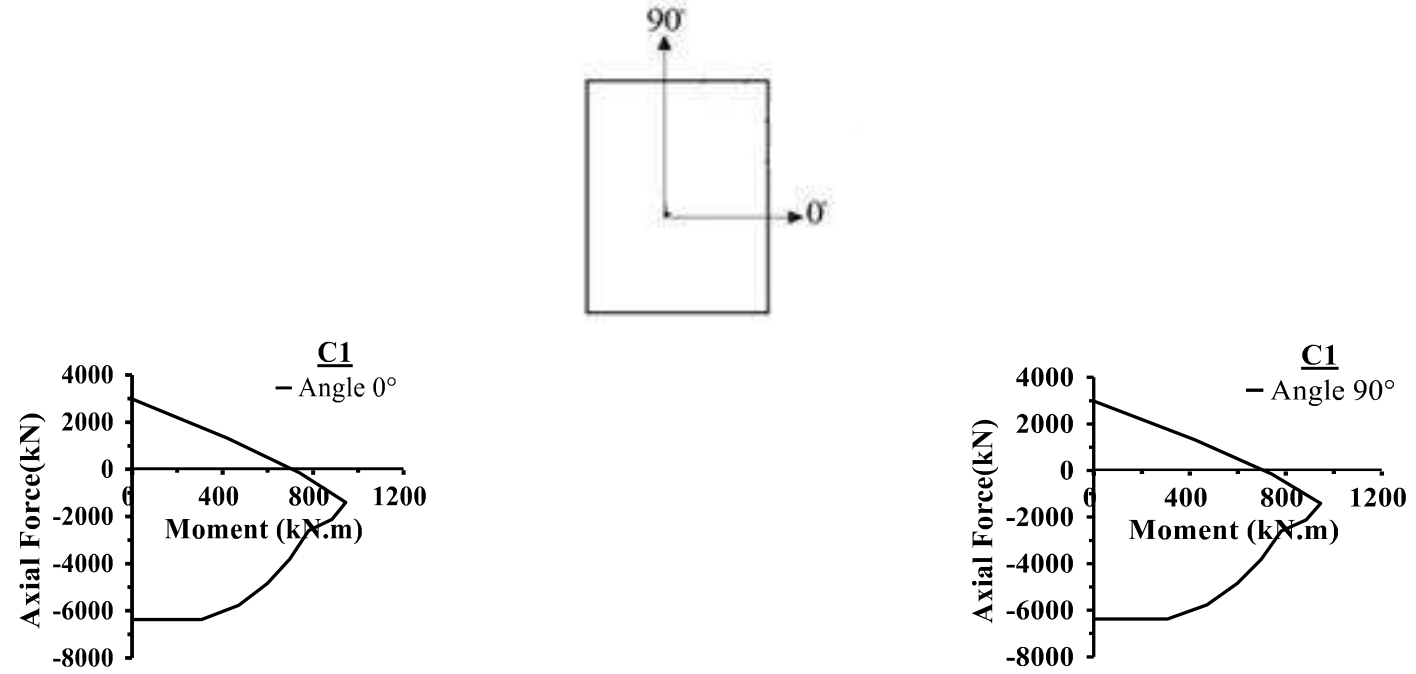

Fig.6. Existing Column-1 Interaction Diagram. 


\subsubsection{Nonlinear Modeling of Shear Wall}

This study defines the shell component by using a multi-layered. This technique gives a better understanding of the seismic behavior of the shear wall. According to the mechanics of composite material, the shell element was defined by this technique. Several layers of varied thickness make form the shell element. Concrete and steel rebar components were assigned to different levels based on their qualities. In SAP2000 [10], the multi-layered shell element is shown in Fig 7. The reinforcing bars are distributed into two layers according to an existing shear wall of the hospital structure. The strain and curvature of the other layers are computed during finite element computations [13]. The stress will be calculated based on the material's constitutive relationships.

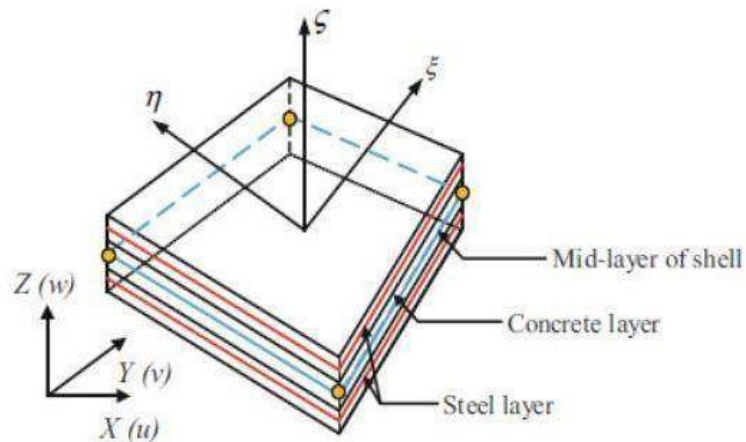

Fig.7. Multi-Layered Shell Element in SAP2000.

\subsection{Properties of Nonlinear Plastic Hinges}

Fig 8 shows the plastic deformation curve that are specified if it satisfies the point definitions. The origin is always Point A and cannot be adjusted. The whole deformation from Point A to Point B takes place within the frame element. The symbol B stands for yielding. The deformation at $\mathrm{B}$ is always zero since the hinges in this investigation are rigid plastic. As a result, there will be no deformation at $\mathrm{B}$, and the hinge will only show plastic deformation beyond $\mathrm{B}$. The ultimate capacity is specified as point $\mathrm{C}$, and the residual strength is defined as point $\mathrm{D}$. Point $\mathrm{E}$ denotes complete failure. As demonstrated in the figures, the load will be reduced to zero force/moment beyond $\mathrm{E}$.

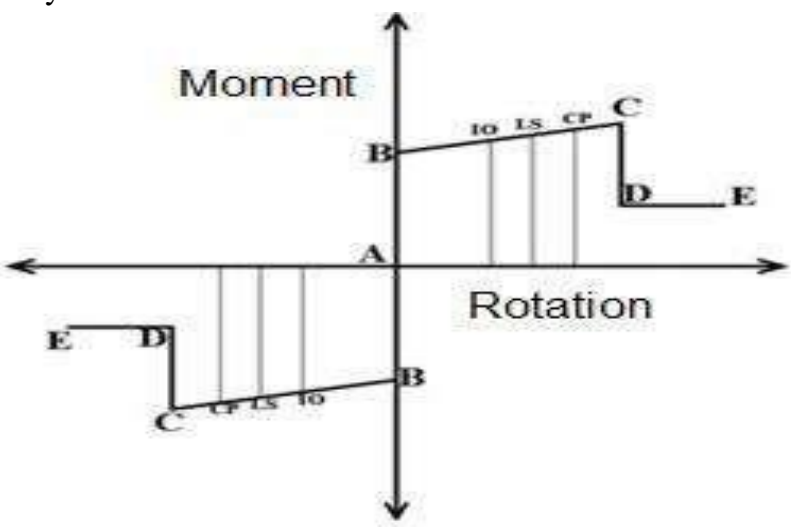

Fig.8. The curve of Actual Rigid- Used for Hinges. 


\subsubsection{Implementation of Moment- Rotation Relationship in Models}

In SAP 2000 [10], the plastic deformation curve for hinges was implemented. On a momentrotation diagram, A, B, C, D, and E must all be points. Where plasticity in the member is expected to occur, the curvature must be checked with a defined plastic hinge length, Lp. According to Park and Pualy [14] calculation, the plastic hinge length was assumed in (1).

$L_{p}=0.5 * H$

For all section types with an expected shear wall, the length of the plastic hinge was calculated to equal half the depth of the member. The depth of each member and the lengths of plastic hinges employed are summarized in Table 2.

Table 2. Member Depths and Plastic Hinge Lengths.

\begin{tabular}{ccc}
\hline Section & $\begin{array}{c}\text { Depth } \\
(\mathrm{mm})\end{array}$ & $\begin{array}{c}\text { Hinge Length } \\
(\mathrm{mm})\end{array}$ \\
Beams & & \\
B (1-15) & 350 & 175 \\
B (12) & 500 & 250 \\
Columns & & \\
C (1,4) & 600 & 300 \\
C (2,5) & 1250 & 625 \\
C3 & 1000 & 500 \\
C6 & 500 & 250 \\
\hline
\end{tabular}

\subsection{Elastic Response Spectrum and Ground Motions}

ISC-2017 [15] was used to determine the MCE and DBE elastic response spectra. To get the desired MCE, the established design spectral accelerations, Sa, were multiplied by 1.5. R, 0), $\mathrm{Cd}$ ), and I have values of $4.5,2.5,5$, and 1.5, respectively. The Halabjah earthquake's acceleration records were obtained from the Iraqi seismic network at the Iraqi Meteorological Organization and seismology (IMOS). In this study, two components were considered: X and Y components, which reflected the building's planning axis. The two components were analyzedand the response spectrum was conducted using PRISM software, as shown in Fig 9. 


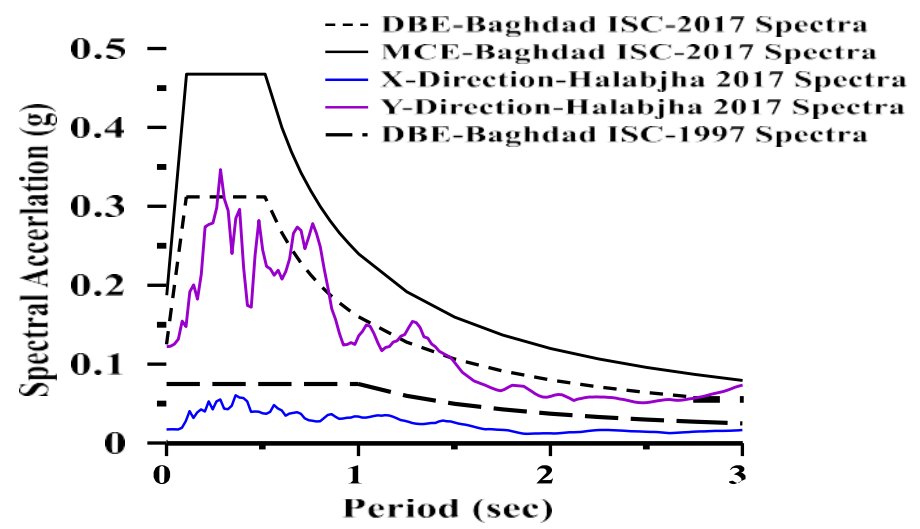

Fig.9. Response Spectrum Used in the Study.

\subsection{Effect of Pounding}

\subsubsection{Studying of the Pounding Effect of Thalassemia Centre Building}

Thalassemia Centre Building consists of two parts as shown in Fig 10. The expansion joint width is equal to $175 \mathrm{~mm}$ between the two parts of the building. According to ISC-2017, The maximum inelastic response displacement $(\delta \mathrm{xt})$ must be allowed by separations. $\delta$ xt shall be determined at critical locations using the following equation, taking into account the structure's translational and torsional displacements, as well as torsional amplifications, where applicable:

$\delta_{x}=\frac{C_{d} \delta_{\max }}{I_{e}}$

Where $\delta \mathrm{x}$ denotes the max. elastic displacement at the critical point. Adjacent structures must be separated by at least $\delta \mathrm{x}$, which is calculated as follows:

$\delta_{\mathrm{xt}}=\sqrt{\left(\delta_{\mathrm{x} 1}\right)^{2}+\left(\delta_{\mathrm{x} 2}\right)^{2}}$

where $\delta \mathrm{x}_{1}$ and $\delta \mathrm{x}_{2}$ are neighboring structures maximum inelastic response displacements at their adjacent edges. In this study, eight cases have considered its effect to study the pounding effect on the building, the eccentricity, and the orthogonal direction of the seismic loads. Table 3 presents the seismic loading example that was applied. 


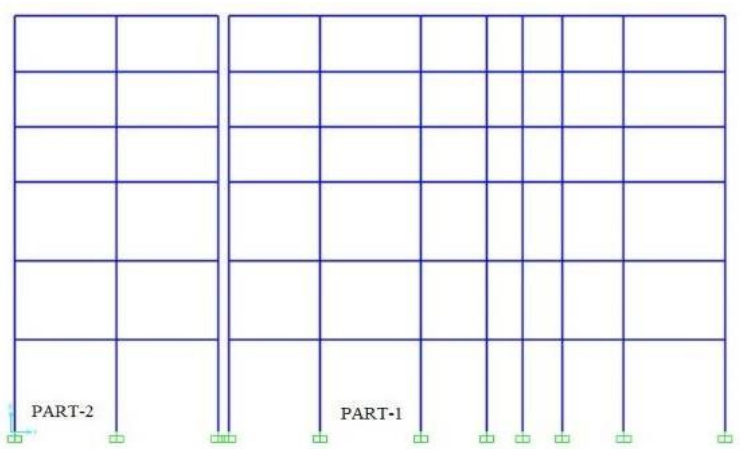

Fig. 10. Expansion Joint Between Two Parts of Building.

Table 3. Seismic Loads Cases.

\begin{tabular}{cccc}
$\begin{array}{c}\text { Seismic } \\
\text { Load Case }\end{array}$ & Eccentricity & $\begin{array}{c}\text { Seismic } \\
\text { Load Case }\end{array}$ & Eccentricity \\
EQ-X1 & 0.05 & EQ-Y1 & 0 \\
EQ-X2 & -0.05 & EQ-Y2 & 0 \\
EQ-X3 & 0 & EQ-Y3 & 0.05 \\
EQ-X4 & $\mathbf{0}$ & EQ-Y4 & -0.05 \\
\hline
\end{tabular}

Eight seismic load combination is considered to study the pounding effect on the building as follows:
1- EQ1=EQ-Y1+0.3EQ-X1
2- $\mathrm{EQ} 2=0.3 \mathrm{EQ}-\mathrm{Y} 1+\mathrm{EQ}-\mathrm{X} 1$
3- $\mathrm{EQ} 3=0.3 \mathrm{EQ}-\mathrm{Y} 2+\mathrm{EQ}-\mathrm{X} 2$
4- $\mathrm{EQ} 4=\mathrm{EQ}-\mathrm{Y} 2+0.3 \mathrm{EQ}-\mathrm{X} 2$
5- EQ5=0.3EQ-Y3+EQ-X3
6- EQ6=EQ-Y3+0.3EQ-X3
7- $\mathrm{EQ7}=0.3 \mathrm{EQ}-\mathrm{Y} 4+\mathrm{EQ}-\mathrm{X} 4$
8- EQ8=EQ-Y4+0.3EQ-X4 (7 b)

\subsubsection{Pounding Effect Results}

Fig 11 and Table 4, present the results of the pounding effect on the thalassemia center building by various seismic load cases. From Figure, the pounding will have happened from two combination load cases (EQ-5 and EQ-6) between the two parts of the building. 
(a)

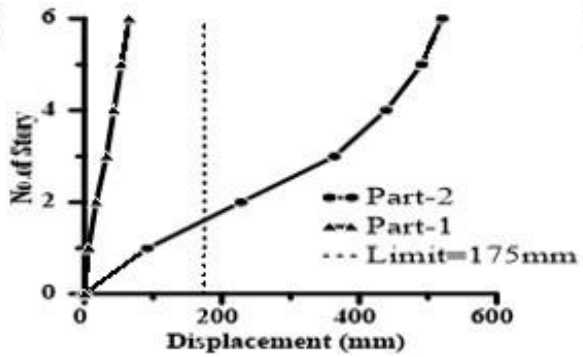

(b)

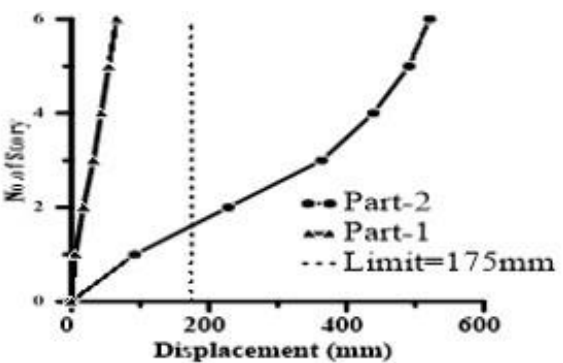

Fig.11. Pounding Effect Between Two Parts of Building. a) 1st Load Combination Case and b) 3rd Load Combination Case.

Table 4. Pounding Values between Two Parts.

\begin{tabular}{|c|c|c|c|c|}
\hline \multirow{3}{*}{$\begin{array}{l}\text { Seismic Combination } \\
\text { Load Case }\end{array}$} & \multicolumn{2}{|c|}{ Building } & \multirow{3}{*}{$\begin{array}{c}\text { Maximum } \\
\text { Elastic } \\
\text { Displacement } \\
\left(\boldsymbol{\delta}_{\mathrm{xt}}\right)(\mathrm{mm})\end{array}$} & \multirow{3}{*}{$\begin{array}{l}\text { Limit } \\
(\mathrm{mm})\end{array}$} \\
\hline & Part-1 & Part-2 & & \\
\hline & $\boldsymbol{\delta}_{\boldsymbol{x}}(\mathrm{mm})$ & $\boldsymbol{\delta}_{\boldsymbol{x}}(\mathrm{mm})$ & & \\
\hline $\begin{array}{c}\text { 1st Load Combination } \\
\text { Case }\end{array}$ & 124 & 470.4 & 486.47 & 175 \\
\hline $\begin{array}{c}\text { 3rd Load Combination } \\
\text { Case }\end{array}$ & 118 & 450.2 & 465.40 & 175 \\
\hline
\end{tabular}

\subsection{Modelling of Diaphragm}

The floor slabs of the buildings were modelled as a 'rigid diaphragm'. Based on pounding effects, the rigid diaphragm represented two parts of the building as one part. In the present work, such diaphragms were modelled for every story of the building.

\subsection{Model Analysis and Dynamic Characteristics}

By using SAP 2000 [10], the model analysis has been performed. Fig. (12) presents the dynamic characteristics of the whole building. The first mode shape represents displaced sway,with a higher inter-story drift at the bottom and a decreasing inter-story drift as the structure rises as shown in Fig 12. 


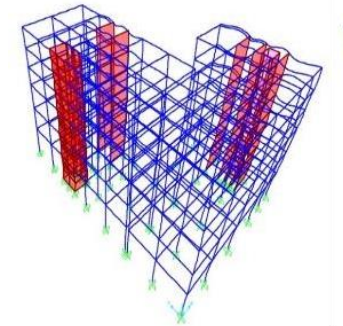

Mode- $1, \mathrm{~T}=0.33 \mathrm{sec}$

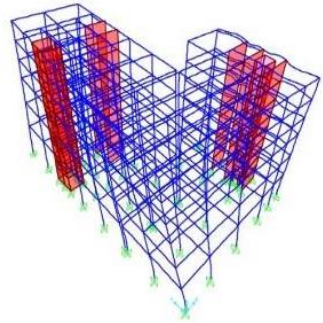

Mode- $2, \mathrm{~T}=0.27 \mathrm{sec}$

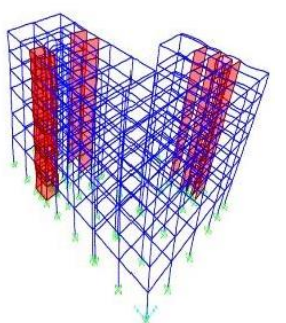

Mode- $3, \mathrm{~T}=0.24 \mathrm{sec}$

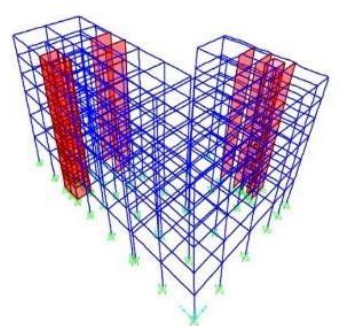

Mode- $4, \mathrm{~T}=0.19 \mathrm{sec}$

Fig. 12. Modes Shape of Thalassemia Centre Building.

\subsection{Lateral Load Distributions}

By calculating the base shear forces and displacements connected to the advancement of yielding in building elements at various phases, the pushover study determines the building levels. According to equation (8), lateral forces are applied in proportion to the story masses and the square height of the floor.

$\mathrm{F}_{\mathrm{i}}=\frac{\mathrm{m}_{\mathrm{i}} \mathrm{h}_{\mathrm{i}}^{k}}{\sum_{\mathrm{j}=1}^{\mathrm{i}} \mathrm{m}_{\mathrm{j}} \mathrm{h}_{\mathrm{j}}^{k}}$

The mass and height of the $i^{\text {th }}$ floor are represented by $m_{i}$ and $h_{i}$.

The original load distribution was employed in the analyses for each direction. Pushover analyses in both directions use the same lateral load distribution Fig 13.

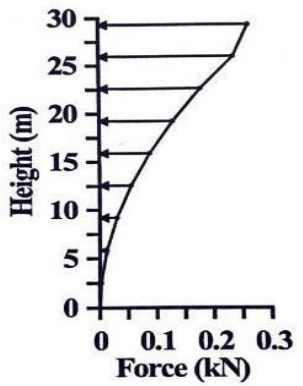

Fig. 13. Distribution of the Lateral Load for Pushover Analysis.

\subsubsection{Implementation of Pushover Analysis and Results}

After the gravity pushover, the lateral pushover analysis in the two directions $\mathrm{X}$ - and -Y was done under displacement control. The structure is pushed to one side until a collapse mechanism occurs. As a bare frame, the models used in the pushover analysis. 


\subsubsection{Pushover Analysis Results}

In the real situation of the Thalassemia Centre Building, the implementation of pushover analysis in two parts of the building has been performed. Fig 14 shows the Part-1, Part-2, and 2parts together of the Thalassemia Centre Building.

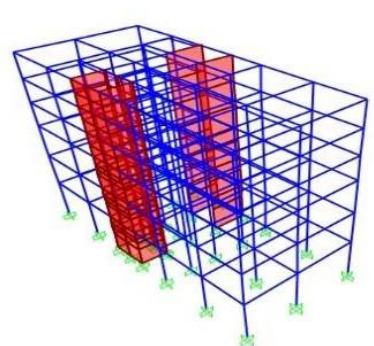

a) Part-1

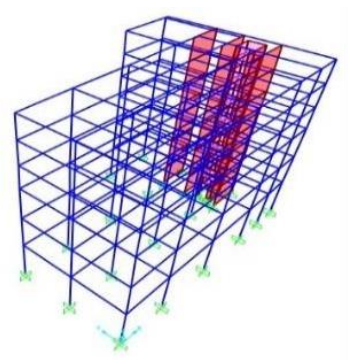

b) Part-2

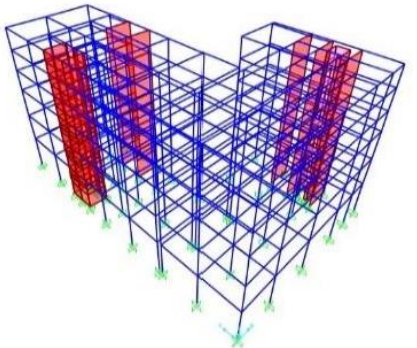

c) 2 Parts together

Fig. 14. Thalassemia Centre Building under study.

\subsection{Capacity Curve Results}

Under the effect of the 2017 Halabjha earthquake, the building (for the two parts) was impacted by the earthquake. Fig 15 illustrated the capacity curves of the real situation of the building with the suggested retrofitted technique.

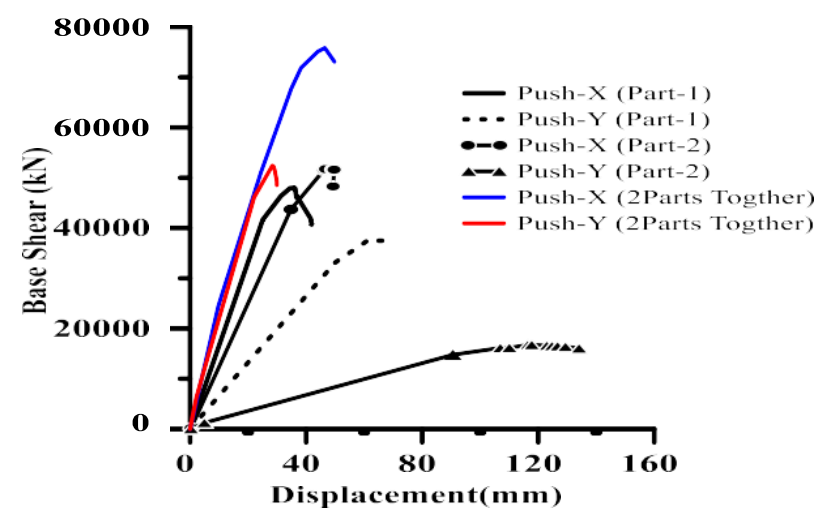

Fig. 15. Capacity Curves of Thalassemia Center Building Parts.

\subsection{Performance Point Results According to ATC-40}

Figure 16 and Table 5 demonstrate the building's performance level using the capacity spectrum technique based on ATC-40 [1] with 5\% initial dampening. 


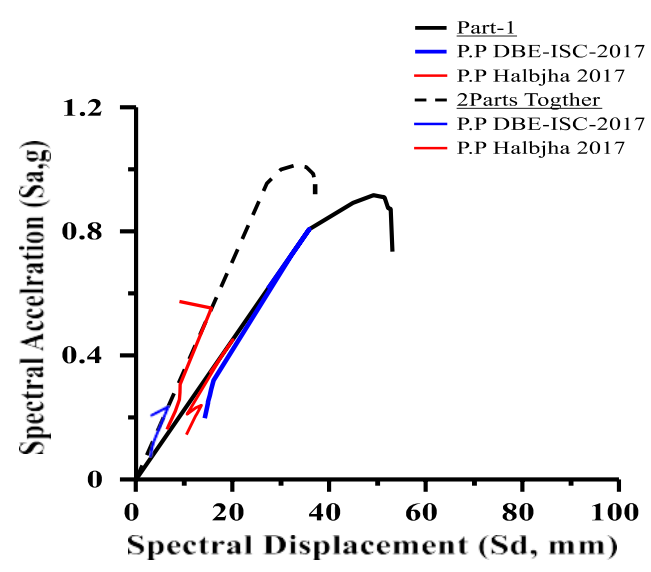

(a) CS for Push-X

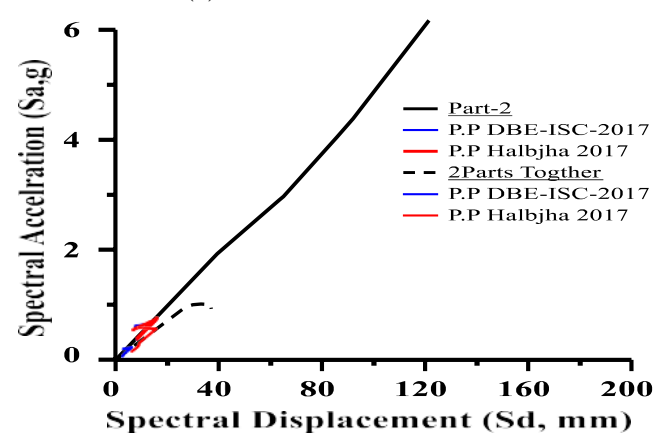

(c)CS for Push-X

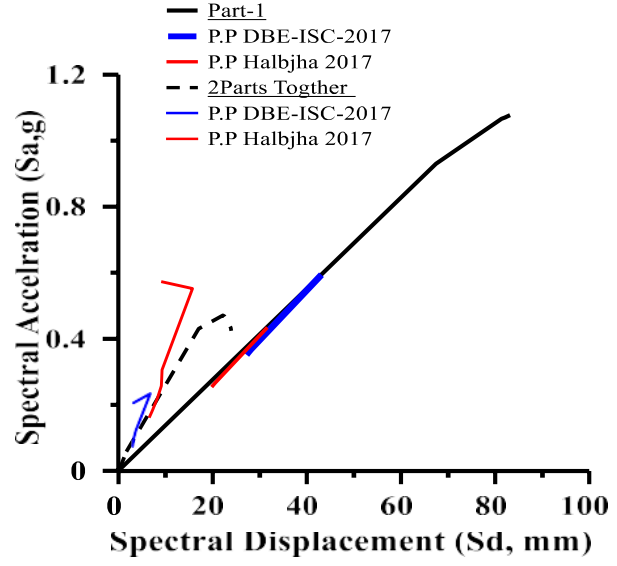

(b)CS for Push-Y

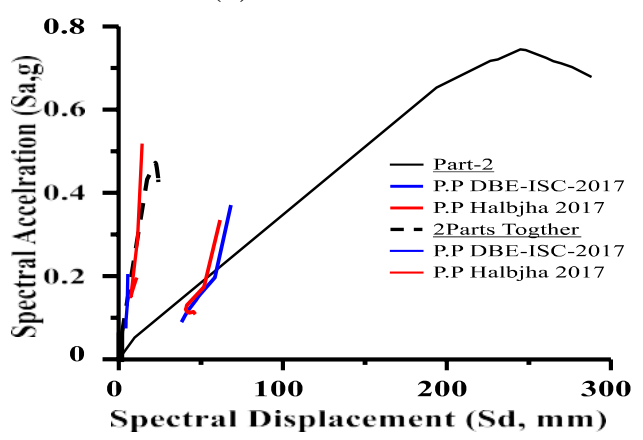

(d)CS for Push-Y

Fig. 16. Capacity Spectrum for Push-X and Push-Y for Part-1( DBE, ISC-2017and Halabjah-2017).

Table 5. States of Performance Points According to ATC-40 for Part-1

\begin{tabular}{|c|c|c|c|c|c|c|c|}
\hline \multicolumn{4}{|c|}{ Part-1 } & \multirow{2}{*}{$\begin{array}{c}\text { Part-2 } \\
\text { Vb } \\
(\mathbf{K n})\end{array}$} & \multicolumn{3}{|c|}{$\begin{array}{l}\text { 2Parts } \\
\text { together }\end{array}$} \\
\hline \multicolumn{2}{|c|}{$\begin{array}{l}\text { Direction and } \\
\text { Earthquake } \\
\text { level }\end{array}$} & $\begin{array}{c}\mathbf{V b} \\
(\mathbf{k N})\end{array}$ & $\begin{array}{c}\text { Roof } \\
\text { Displacement } \\
\Delta \text { roof(mm) }\end{array}$ & & $\begin{array}{c}\text { Roof } \\
\text { Displacement } \\
\Delta \text { roof(mm) }\end{array}$ & $\begin{array}{c}\mathbf{V b} \\
(\mathbf{k N})\end{array}$ & $\begin{array}{c}\text { Roof } \\
\text { Displacement } \\
\Delta \text { roof(mm) }\end{array}$ \\
\hline \multirow[t]{2}{*}{ X } & $\begin{array}{c}\text { DBE } \\
\text { ISC-2017 }\end{array}$ & 31792.38 & 19.12 & 10097.43 & 8.19 & 55723.46 & 21.00 \\
\hline & $\begin{array}{c}\text { MCE } \\
\text { ISC-2017 }\end{array}$ & 43422.36 & 27.4 & 16458.34 & 13.22 & 98396.72 & 38.00 \\
\hline \multirow[t]{2}{*}{$\mathrm{Y}$} & $\begin{array}{c}\text { DBE } \\
\text { ISC-2017 }\end{array}$ & 21161.60 & 31.95 & 5313.338 & 30.80 & 42356.10 & 33.00 \\
\hline & $\begin{array}{c}\text { MCE } \\
\text { ISC-2017 }\end{array}$ & 31372.08 & 17.36 & 7509.58 & 24.68 & 50630.50 & 27.00 \\
\hline $\mathrm{X}$ & $\begin{array}{c}\text { Halabjah } \\
2017\end{array}$ & 17759.30 & 10.69 & 9504.60 & 7.72 & 43116.06 & 16.00 \\
\hline $\mathrm{Y}$ & $\begin{array}{c}\text { Halabjah } \\
2017\end{array}$ & 15521.95 & 23.43 & 4852.9 & 27.89 & 33707.38 & 28.00 \\
\hline
\end{tabular}




\subsection{Plastic Hinge Mechanism}

Fig 17 presents the plastic hinge mechanism for Part-1, Part-2, and 2 parts together, it shows that the plastic hinge is formed in the structural elements, this reflects that the two parts cannot be insufficient to resist the Halabjha earthquake as a bare frame.

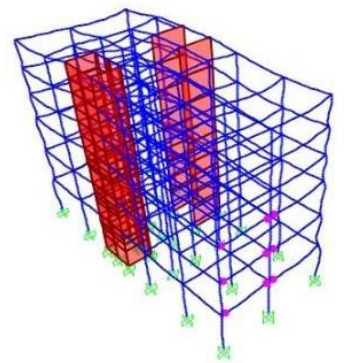

a) X-.Direction (DBE), Part-1

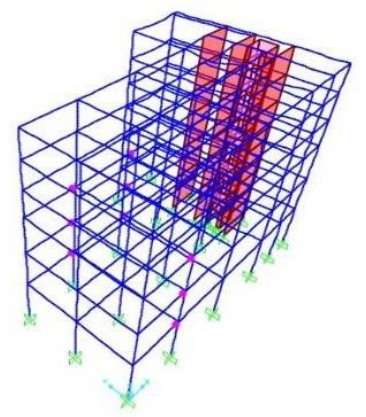

c) X-Direction (DBE),Part-2

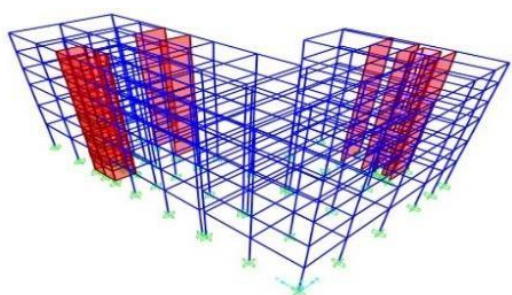

d) X-Direction (DBE),2Parts togther

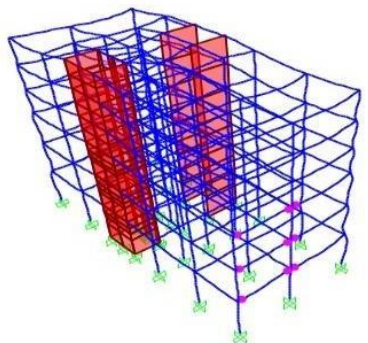

b) Y-.Direction (DBE),Part-1

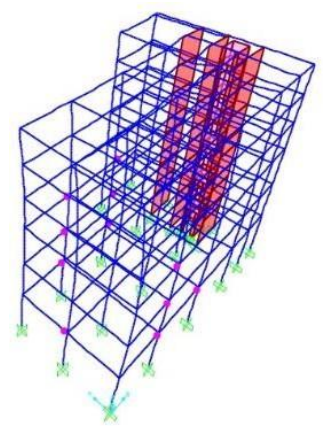

b) X-Direction (DBE), Part-2

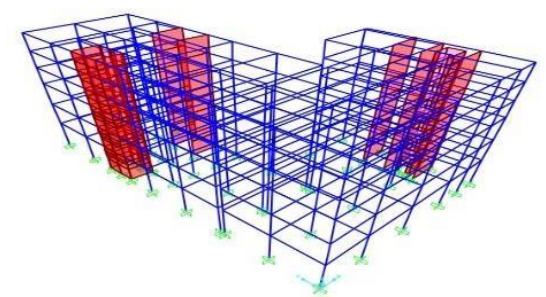

e) X-Direction (DBE), 2Parts together

Fig. 17. Plastic Hinge at Performance Point. 


\section{Conclusions}

It can be concluded, based on the limitations of assessment codes and testing procedures, that:

1. The technique leads to an increase in the base shear to $61.77 \%$ and $51.51 \%$ higher than the base shear of Part- 1 in the $\mathrm{X}$ and $\mathrm{Y}$ directions respectively, on other hand, it leads to a decrease in the roof displacement to $8 \%$ and $27 \%$ less than the roof displacement of Part-1 in the $\mathrm{X}$ and $\mathrm{Y}$ directions respectively.

2. In the $\mathrm{X}$ and $\mathrm{Y}$ directions, the mechanism causes the base shear to increase to 28.51 percent and 70.85 percent higher than the base shear of Part-2, respectively; on the other hand, it causes the roof displacement to decrease to 108.16 percent and 387 percent less than the roof displacement of Part-2, respectively.

3. The results of the plastic hinge mechanism clarified that Thalassemia Centre Building (as one entity) doesn't form any plastic hinge with the Halabjah response spectra and MCE of ISC-2017, and the building was in Immediate occupancy.

4. The torsion effect, the results explained that no torsion effect on the building.

5. The inter-story drift, the result showed that the inter-story drifts within acceptable limits.

6. According to ISC-2017, the values of spectral response acceleration at short and $1 \mathrm{sec}$ periods were suitable and appropriate for use in seismic analysis and design. According to the DBE response spectrum of ISC-2017, the rise in base shear in X and Y directions was 22.62 percent and 20.42 percent higher than the values of Halabjah earthquake spectra, respectively.

7. According to the DBE response spectrum, the roof displacement increased by $23.80 \%$ and $20 \%$ in the $\mathrm{X}$ and $\mathrm{Y}$ directions, respectively, compared to the Halabjah earthquake spectra. [9] According to the MCE response spectrum of ISC-2017, the increase in base shear was 56.18 percent in $\mathrm{X}$ directions and 33.42 percent in $\mathrm{Y}$ directions, respectively, compared to the values of Halabjah earthquake spectra.

8. In the $\mathrm{X}$ and $\mathrm{Y}$ directions, the increase in roof displacement was 57.89 percent and 40.74 percent higher than the values of Halabjah earthquake spectra, respectively.

9. This Technique of retrofitting will apply to Thalassemia Centre Building becausethe Ministry of Health has not taken any previous or current action of rehabilitation.

\section{Acknowledgments}

The authors would like to express their gratitude to Mustansiriyah University (www.uomustansiriyah.edu.iq) in Baghdad, Iraq, for their assistance with this project.

\section{References}

[1] Applied Technology Council, "Seismic Evaluation and Retrofit of Concrete Buildings", Report No. SSC 9601: ATC-40, Vol.1, Redwood City, California,1996.

[2] Federal Emergency Management Agency, "Pre Standard and Commentary for the Seismic Rehabilitation of Buildings", FEMA-356, Washington, D.C, 2000. 
[3] Federal Emergency Management Agency, "NEHRP Guidelines for the Seismic Rehabilitation of Buildings", FEMA-273”, Washington, D.C, 1997.

[4] Deng, M.K., Liang, X.W., Wang, Q.L. and Cai, D.Y., "Research on Calculating Methods of Story Drift for Reinforced Concrete Shear Wall Structures", Journal of Earthquake Engineering and Engineering Vibration 28:3, 95-103, 2008.

[5] Just, G., Koch, I., Brod, M., Jansen, E., Gude, M. and Rolfes, R. "Influence of Reversed Fatigue Loading on Damage Evolution of Cross-Ply Carbon Fibre Composites. Materials", 1153, doi:10.3390/ma12071153, 2019.

[6] Bagchi, A., "Evaluation of The Seismic Performance of Reinforced Concrete Buildings", Ph.D., dissertation to Civil and Environmental Engineering, Carleton University, Ottawa, Canada, 2001.

[7] He, H., Cong, M. and Lv, Y., "Earthquake Damage Assessment for RC Structures Based on Fuzzy Sets", Mathematical Problems in Engineering, Hindawi Publishing Corporation, Article ID 254865, 2013.

[8] Dumaru, R., "Seismic Performance Assessment and Strengthening Techniques for Existing Reinforced Concrete in Nepal", Ph.D., dissertation to the Faculty of Engineering of the University of Porto, Portuguese public, 2018.

[9] Guide for Seismic Rehabilitation of Existing Concrete Frame Building and Commentary (ACI 369R-11), Reported by ACI Committee 369,2011.

[10] Computers and Structures, SAP2000 v22 Integrated finite element analysis and design of structure basic analysis reference manual, 2012.

[11] Bolander, J., "Investigation of Torsional Effects on Thirteen-Story Reinforced Concrete FrameWall Structure Modeled in ETABS and SAP2000 Using Linear and Nonlinear Static and Dynamic Analyses", M.Sc. thesis submitted to civil engineering, University of California, San Diego, 2014.

[12] Kasimzade, A., Nematli, E., Mammadzada,V. and Atmaca,G., "New Design Criteria in Performance Based Earthquake Engineering", International Journal of Trend in Scientific Research and Development (IJTSRD), Vol: 4, 2020.

[13] Fahjan, Y.M, Kubin, J., and Tan, M.T., "Non-Linear Analysis Methods for Reinforced Concrete Buildings with Shear Walls", 14 European Conference on Earthquake Engineering, 2010.

[14] Park, R. and Paulay, T., "Reinforced Concrete Structures". New York: John Wiley \& Sons, 1975.

[15] Ministry of housing and construction, Iraq "Iraqi seismic code requirement for buildings",2017. 